ment. (Because of the exam's purpose, individual grades are not revealed.) This is the first time Brazilian higher education institutions have had to bow to nationwide, systematic evaluation. Although its introduction produced intense opposition from some universities and student groups, the exam is now in its second year, and has had a remarkable impact on Brazil's educational system, particularly in the private sector, which is scrambling to get good marks, and thereby forcing the public institutions to do the same.

In addition to the implementation of a national exam, new legislation has been introduced to distinguish between proprietary, profit-oriented private institutions and nonprofit ones. Under the legislation, for-profit schools would have to pay taxes as any other business, but would be allowed more freedom to run their institutions as they see fit. Nonprofit schools, on the other hand, would be held to a stricter set of educational controls within the communities they are supposed to serve. To date, there are no takers for the first alternative, and the control mechanisms for the second are still not fully implemented. The idea that education can be a legitimate business is a completely new and revolutionary one in the Brazilian context.

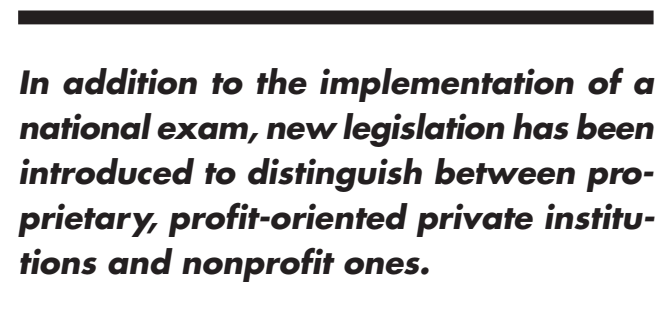

The country's Ministry of Education is also trying to change public universities-an interesting and innovative project, but one that is encountering great resistance. The idea is to provide universities with full autonomy to control their own resources, set their own policies, and establish their own rules regarding personnel. In this effort they will be provided with monies each year based on past performance. Today, salaries are set by the government, academic and administrative staff are civil servants protected by full stability, and the universities have no access to the resources used for salaries-about 90 percent of the funds they receive. University administrators and faculty fear that the proposed changes could mean that the federal government is trying to do away with its universities. To soothe these fears, the Ministry of Education has proposed that 75 percent of the federal government's budget for education should be earmarked for federal higher education institutions (public and basic secondary education are the responsibility of state and local governments, although the federal government plays important supplementary roles). Ratification of this project requires a constitutional amendment. Because it is feared by universities and goes against the general policy of various economic authorities, the project's future is uncertain.

Other initiatives and changes are also in the works. These include reforming the National Education Council, the reorganization of technical education programs, changes in student admissions procedures, the introduction of periodical reaccreditation of universities, and the reorganization of student loans for the private sector.

Ultimately, the forces reshaping Brazilian higher education will be the growing demand for university access due to the expansion of secondary education and the expanding market for better qualified professionals-a consequence of opening the country's economy to international competition and economic growth. With the help of ongoing reforms, the public sector is already organizing to respond to these new challenges and opportunities. Undoubtedly, the private sector will likewise follow suit.

\section{Secularism and Education in the Philippines and the United States}

\section{Peter M. Collins}

Peter Collins is a professor in the School of Education, Marquette University. Address: School of Education, P.O. Box 1881, Marquette University, Milwaukee, WI 53201 USA.

$\mathrm{C}$ ulture in the United States in the second half of the 20th century will be characterized by future historians as privately religious and publicly secular. While a huge majority of individual citizens claim to be Christian, the culture has tended to become increasingly secularist. This secularism features a pronounced indifference, rather than a manifested antipathy, toward religion. Dawson has distinguished this indirect form of secularism from the directly secularist approaches found in modern history in continental Europe. ${ }^{1}$

A prime example of secularism in late 20th-century American culture is found in public higher education. The subtitle of Marsden's recent book, From Protestant Establishment to Established Non-belief, signifies the pattern of development. ${ }^{2}$ According to the author, Americans have become so thoroughly imbued with the spirit of secularism that we are even distorting our own history. He elaborates the gross omission of attention to the role of religion in the history of American higher education-which overlays the centrality of Christianity in state colleges and universities well into the 20 th century. A similar misrepresentation is manifested in a comparison of the writings of outstanding educators in the history of West- 
ern Europe (such as Comenius, Pestalozzi, Froebel, and Montessori) with recent commentaries on their educational contributions. The latter fail to acknowledge the religious and philosophical principles that inspired the lives and the pioneering pedagogical efforts of these individuals.

\section{A prime example of secularism in late 20th-century American culture is found in public higher education.}

For most of the first five months of 1996, I resided in the Philippines, teaching for one trimester at De La Salle University (DLSU) in Manila and for five weeks (summer session) at the University of the Philippines (UP) in Diliman, Quezon City. At DLSU, a Catholic university conducted by the Christian Brothers, I taught a graduate course and an undergraduate course in the Department of Philosophy (College of Arts and Sciences) and a graduate course and undergraduate course (in philosophy of education) in the College of Education. At UP, the state university with its flagship campus at Diliman, I taught a graduate course (in philosophy of education) in the College of Education. One of my purposes in going to the Philippines to teach was to ascertain similarities and differences between cultures (especially higher education) in the two countries relative to the phenomenon of secularism.

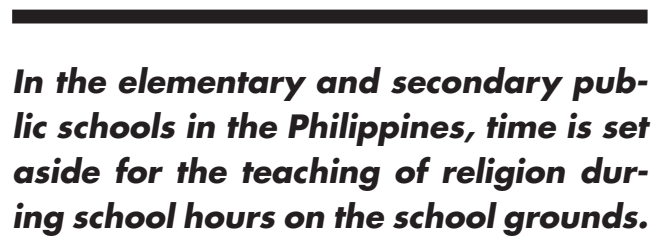

In the elementary and secondary public schools in the Philippines, time is set aside for the teaching of religion during school hours on the school grounds. Students can choose to attend religion classes sponsored and taught by persons representing specific religions (the most popular of which is Catholicism), or they can take a course called Values Education, which is not affiliated with any particular religion. My understanding is that they must take either a course in a specific religion or Values Education, the latter presumably grounded in some kind of religious and/ or philosophical reflection.

My brief experiences in the Philippines manifested the importance of religion in higher education there as wellin campus life generally, in curriculum planning, and in classroom discussion. The observance of the Angelus, visits to the chapel, and attendance at daily Mass on the DLSU campus exemplify the first. Secondly, according to one of my former graduate students at the University of the Philippines who is on the faculty of the College of Home Economics on that same campus, the faculty of that college had been attempting to establish goals to permeate all courses taught in the college. Among these goals were love of country and love of God-at the state university! Thirdly, concerning classroom discussion, I noted carefully the responses of my graduate students at UP to questions raised in the introduction to the course concerning their own personal "fundamental values." They spoke freely, openly, and with strong convictions about their religion and the Bible. One even quoted the Bible. This is not my experience in the United States-even in a Catholic university!

My brief experiences in the Philippines
manifested the importance of religion
in higher education there as well-in
campus life generally, in curriculum
planning, and in classroom discussion.

I am not certain what all of this means. However, it appears that there is generally more consistency in the Philippines than in the United States between private religious judgments and the public forum (including public education). Whereas both cultures represent a substantial challenge for the philosophy of education, educators in the Philippines can take advantage of the readiness of Filipinos to discuss their religion publicly in order to help students reflect upon their religion and to pursue philosophy-and to relate both their religion and their philosophy to their personal living, and to planning and implementing formal processes of education.

The fact that religious pluralism permeates U.S. culture to a far greater degree than is true in the Philippines ought not to cause Americans to abandon public attention to religious and philosophical questions, especially in formal education.

\section{Notes}

1. Christopher Dawson, The Crisis of Western Education (New York: Sheed \& Ward, 1961).

2. George M. Marsden, The Soul of the American University (New York: Oxford University Press, 1994). 